\title{
Dorothy Heathcote ile İlgili Biyografik Ayrıntılar
}

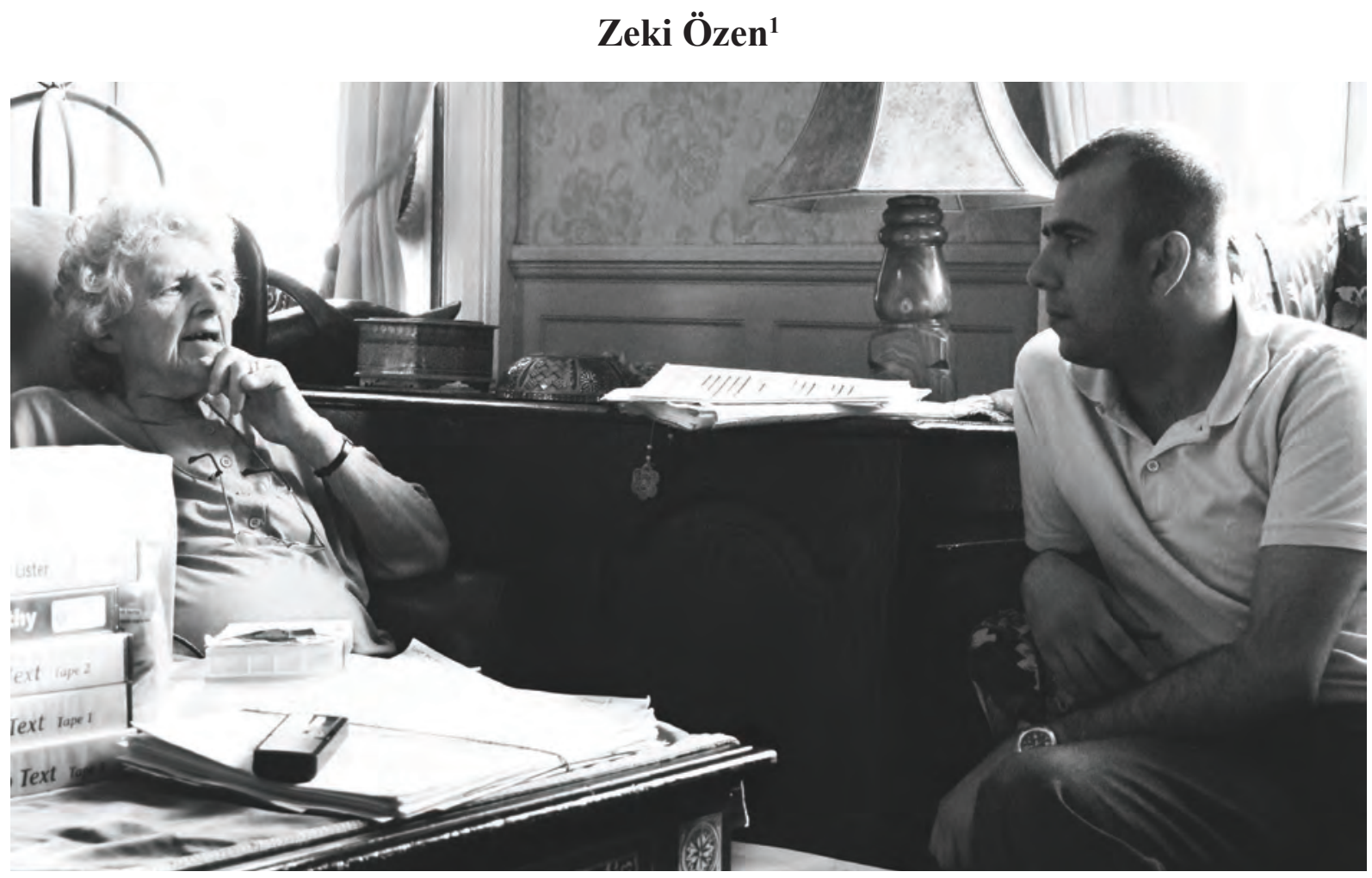

Dorothy Heathcote, 29 Ağustos 1926 yılında Batı Yorkshire'da Steeton köyünde Dorothy Shutt ismi ile dünyaya gelmiştir. Üç yaşından altı yaşına kadar annesinin ailesi ve ailenin sekiz genç çocuğu ile beraber yaşamıştır. Dul bir kadın olan annesi Steeton'un yakınlarında şehirde çalışmaya gitmiş ve bu süreden kısa bir süre sonra dayılarından birisi yine çalışmak için evi terk etmiştir. Çocukluk döneminde belirsiz anılara sahip olan Dorothy Heathcote bu yetişkin ailedeki tek çocuk olarak kabul gördüğünü ve sevildiğini ama hiçbir zaman bebek gibi muamele görmediğini dile getirir (Hesten,1993).

Küçük yaşlardan itibaren kendisi gibi olmak için çok uğraş vermiştir. "Bir biçimde dikkate değer bir kişiydim, yaşamım boyunca birine aykırı düşmemeyi istediğimi sanmıyorum" tümceleri ile değişik olma konusundaki titizliğini göze çarpar bir biçimde dile getirmiştir. Çocukluk yıllarında kendisine liderlik eden, toplumsal ve ahlaki vicdana sahip olan bir kadın rehberden, Dorothy Clough'tan etkilenmiştir. Çocukluğuna ilişkin bu imgeyi Heathcote :

"Dorothy Clough yerden tavana kadar bir kitaplı̆̆a sahipti, Bazı popüler kitaplar, gerçek kırmızı bir deri ile bağlanmış ve kalın sayfaları olan klasiklerin tüm serileri, hala ellerimde hissedebiliyorum... Nasıl bir sanatçılıktır bilirsiniz... ellerimin dokunduğu herşeyi okudum. Kitaplı̆̆ kullanmak için sonsuz özgürlüğe sahiptim ve hiç kimse onlarl geri getirip getirmediğimi kontrol etmiyordu “

tümceleri ile ifade eder (Hesten, 1993).

1 Arş. Gör. Bil.Uzm. Ankara Üniversitesi, Eğitim Bilimleri Fakültesi, zozen@ankara.edu.tr 
Dorothy Heathcote, kendi ülkesinde uygulanan ve 11+ adı verilen ilköğretimden ikinci kademeye geçiş sınavını geçememiştir. Bu nedenden dolayı köy okulunda eğitim görmeye devam etmek zorunda kalmıştır. Akademik bir başarısızlıkla itham edilmesine rağmen Yorkshire Değirmenin'de dönemin savaş paraşütlerini dokuyanlardan biri olarak bir tür dönüşüm yaşamıştır. Zorunlu olarak kendi kendini eğiten birisi olarak bitmeyen enerjisi ve farklı düşünceleri ile karizmatik yapıda biri olmuştur.

1945 yılında savaşın sonlarına doğru 19 yaşlarındayken Bradford'ta bulunan Esme Kilisesi Tiyatro okuluna kabul edilmiştir. Bu okulun masrafları Dorothy Heathcote'un annesinin 3 tezgahın sorumluluğunu alması şartıyla, çalışmış olduğu imalathane sahibi tarafından karşılanmıştır (Hesten, 1993).

Dorothy Heathcote kendisiyle yapılan görüşmede bu yaşantıyı,

"Annemin eklem ağrıları vardı. Bazen dokumacılar gün boyunca oturmazlar ve bu durum bende müthiş bir suçluluk duygusu yaratıyordu. Emekli olması gerekliyken o üç tane tezgahtan sorumlu olarak paraşüt dokumaya devam ediyordu. Hem savaş bitmemişti hem de bu işler yapılmak zorundaydı"

sözcükleri ile belirtmektedir.

Annesi ve annesinin ailesi ile kalabalık bir ev ortamında yetişen Dorothy Heathcote çocukluğunu çalkantılı bir biçimde yaşamıştır. Annesinin iş değişiklikleri, dayılarının iş bulma çabaları ve anneannesinin ona baktığı zamanlar çocukluk döneminin önemli ayrıntıları arasında yer almıştır (Hesten, 1993). Heathcote bu yaşam okulunu ve yaşamının tiyatro ile olan ilişkisini:

“...Köyde iken yaşlı insanlar tarafindan eğitilmiştim, büyükannem, teyzelerim, annem hep konuşuyorlardı böylece eğitildim Aynı zamanda tiyatroda'da çok başarll insanlar tarafindan 3 yll boyunca eğitim aldım. Onlardan bir kadın, okullarla çok ilgileniyordu ve bana 'Sen ögreteceksin'dedi ben ise öğretmeyeceğimi imalathane’ye gidip dokumacılı̆̆a devam edeceğimi söylemiştim. Bana tekrar 'Sen ögreteceksin' dedi. Öğretmeye gitmemeye kararliydım ancak tiyatro okulu ögretmenlerle bir çalışma yaptı ve ben de ögretmenlerle çalışmaya ilgi duymaya başladım. O gece birçok ögretmen sınıfa geldi. Birçoğu Ingilizce ögretmeniydi ve tiyatroyu okullarında istiyorlardı. Böylece birçok ögretmenle tanışmış oldum ve okulların neye benzediğini görmek için onlarla beraber okullarına gittim. Hatırlayın ki ben bir köy okulundaydım bu gittiğim okullar ise çok büyük okullard. Bu nedenle hiçbir zaman drama öğretmeninin ögrettiği yolla ögrretmedim."

19 yaşından 21 yaşına kadar Bradford'ta bulunan "The Northern Theatre School” 'da öğrenciliğini sürdüren Dorothy Heathcote bu süre içerisinde, modern dansın önde gelen insanlarından ve "Modern Educational Dance“ (Modern Eğitimsel Dans)' in yazarı 'Rudolph Laban’ ile tanışmıştır (Hesten, 1993).

28 yaşında iken Newcastle Upon Tyne Üniversitesinde drama eğitimi alanında asistan olmuştur. O dönem Dorothy Heathcote yaşamıyla ilgili önemli bir karar vermek durumunda kalmış ve Durham Üniversitesi'nden ayrılarak yeni açılan Newcastle Üniversitesi'nde görev yapmaya başlamıştır. Kendisinin ayrılması ile oluşan boşluğu ise uzun yıllar beraber çalışacağı meslektaşı Gavin Bolton doldurmuştur. Heathcote, kendisiyle yapılan görüşmede o dönemi 
anlatırken:

“Ben Durham Üniversitesi’ne atanmıştım. Üniversitenin Newcastle bölümü çok büyüktü ve Durham Üniversitesi'nden ayrilmasina karar verdiler. Bana da Durham Üniversitesi'nde mi kalmak istiyorsun yoksa yeni açllacak olan üniversiteye mi geçmek istiyorsun diye sordular. Beraber çalıştı̆̆ım profesör nereye giderse bende oraya giderim diye yanıt verdim. Çünkü bana göre insanlar binalardan daha değerlidir. ... Profesörümle beraber gittim. Daha sonra da ilköğretim okullarına gitmeye başladım çünkü 'Frobel'kursuna atanmıştım ve Frobel kursu ilköğretimdeki çocukların gelişiminde sanatı temel alıyordu. Müzik, Drama, Resim, Dans bir bütün olarak çok önemli bir biçimde dikkate alındılar. Böylece, üniversitedeki ilk dersimi yaklaşık 40 okul müdürüne vermiş oldum.

Şunu düşünsene 24 yaşındayım daha önce hiç ama hiç ders vermemişim, öğretmenlik hakkında bir şey bilmiyorum, bir profesör tarafindan üniversiteye atanmışım ve müdürlerle çalışıyorum. Bu müdürler her defasında benim okuluma gel ve bu anlattıklarını işleyişe dök demeyi sürdürdüler. Elbette ben de ancak o dönemki yaşam şartlarımla okullara gidebiliyordum. Bir çok okula gittim, bir çok sınıfla çalıştım. Ardından yeni Durham Üniversitesi, ben Newcastle’a gittiğim için benim yerime yeni birini istihdam etmek istedi. Ilan verildi ve Gavin Bolton oraya atandl." ifadelerini dile getirmiştir.

Eğitim yaşamına üniversitede devam eden Heathcote, daha sonra birçok farklı ülkede drama çalışmaları yürütmüş birçok farklı yaş grubu ile çalışmalarda bulunmuş ve kendi yaklaşımlarını geliştirmiştir.

1956 yılında Raymond Heathcote ile evlenen Dorothy Heathcote, 1966 yılında 39 yaşında iken kızı Marianne' yi dünyaya getirmiştir. Dorothy Heathcote'un kızını dünyaya getirmesi, öğretmenlik kariyeri boyunca kendi yöntembilimine taze anlayışlar getirmesine olanak sağlamıştır. Heathcote kızı Marianne ve kızının ailesiyle beraber İngiltere'de Derby'de yaşamaktaydi.

\section{Kaynaklar}

Hesten, S. (1993). The Dorothy Heathcote Archive. (Doktora tezi). Manchester Metropolitan University.

Özen, Z. (2011). Dorothy Heathcote'un Yaratıcı Drama Yaklaşımları. Yayımlanmamış Yüksek Lisans Tezi, Ankara Üniversitesi Eğitim Bilimleri Enstitüsü, Ankara. 


\section{Curriculum Vitae for Dorothy Heathcote}

\section{Date of birth:}

29 August $1926-\infty$

\section{E-mail:}

mariannekevin@yahoo.co.uk

\section{Education and early work:}

State education at Steeton Council School, Yorkshire, UK, until age 14 (1940).

1940-1945. Weaver in woollen mill.

\section{Training and early career:}

1945.Obtained scholarship to Northern Theatre School, Bradford, Yorkshire, UK.

1945-1948. Studied dance with Rudolph Laban and theatre with Esmé Church.

1948. Received LRAM (Licentiate of the Royal Academy of Music and Dramatic Art) teaching qualification. Made member of staff at end of course, covering part-time classes for local teachers and business people. Also worked freelance employed by local education authorities.

\section{University career:}

In September 1950, appointed to the University of Durham as full-time lecturer in Drama in Education (Newcastle upon Tyne site).

Worked with experienced serving teachers introducing innovative techniques for using Drama as a basis for curriculum education related with Froebel theories of education.

Awarded Honorary Master of Arts Dunelm (University of Durham).

Transferred, by invitation, to the newly chartered University of Newcastle upon Tyne as full-time lecturer in Drama in Education, continuing to develop the Froebel arts courses with head-teachers and teachers of primary schools in the North-East of England.

Taught full-time and part-time Advanced Diploma courses for experienced teachers who were studying to obtain the Advanced Diploma in Primary Education. This also included travelling to schools all over the UK, supervising teachers on this course.

Launched the first Master of Education course in 'Drama as Education', which attracted many teachers from overseas in addition to UK teachers. Teachers were seconded by their governments to attend the course for a year. 
During these years, invited to teach in many countries throughout the world.

In 1965, appointed Senior Lecturer in the School of Education, University of Newcastle upon Tyne.

Developed three specific innovative systems of work, which are recognised internationally:

1. Mantle of the Expert, involving primary school children and the whole curriculum. Mantle of the Expert is now established as a system which involves developing changes in teacher education. OFSTED are currently examining this system.

2. Rolling role, involving teachers in secondary education working in teams.

3. Commission models, involving relationships of schools with business, museums and industry.

In 1986, retired from full-time lecturing at the University of Newcastle upon Tyne.

From 1986 to present date. Worked on numerous education projects with advisers, universities and teachers.

Work since retirement from the University of Newcastle upon Tyne in 1986:

Taught on various masters in Education courses in the Universities of: Central England, Dublin, London and Derby.

Regularly taught master classes at Birmingham Repertory Theatre related with theatre productions and literary texts, such as: The Crucible, Dracula, The Doll's House, Kensuky's Kingdom, and To Kill a Mocking Bird.

Taught master classes at Highbury Theatre, Birmingham, training actors to interpret text in teams.

Was invited to work with Volkswagen car manufacturers in Wolfsburg, Germany. Provided innovative training for management teams.

Taught British Gas managers to work with apprentices whose work brought them into contact with householders and businesses.

Worked with the new National Health Service Hospital in Hexham, Northumberland, on an educational project designing the new garden. This involved working with high school students and hospital staff.

Ongoing work in schools related with the Creative Partnership Organisation for the UK and Red Earth Theatre, using Mantle of the Expert system, involving drama methods applied as context for the whole school curriculum.

Regular contribution to conferences throughout retirement, including NATD (National Association of Teachers of Drama) and ND (National Drama).

Current work includes working with the training of nurses and doctors, the police in community situations, business management course and teacher education. Work currently in process for Creative Partnerships includes devising a model of working at the site of the Roman British Housesteads Fort in Northumberland, in partnership with the National Trust, English Heritage, the Northumberland Tourist Board and high school students. 


\section{Overseas teaching:}

Worked, by invitation in a number of countries overseas, each for a period of up to six weeks. The teaching involved work with pupils and teachers in their classrooms, observed by teachers and lecturers from colleges and universities in the locality, all of whom were engaged in teacher training.

\begin{tabular}{|c|c|c|}
\hline Date & Place & Sponsored or invited by \\
\hline Various & Dublin, Ireland. & University of Dublin. \\
\hline 1962 & Bombay, Madras, Bangalore, & The British Council. India. \\
\hline 1962 & Aden and The Yemen. & The British Council. \\
\hline 1965 & Warsaw, Poland. & The National Theatre. \\
\hline \multirow[t]{4}{*}{1970} & Amsterdam, The Netherlands. & $\begin{array}{l}\text { A company of professional actors } \\
\text { working in schools. }\end{array}$ \\
\hline & Copenhagen, Denmark. & $\begin{array}{l}\text { University of Copenhagen Teacher } \\
\text { Education. }\end{array}$ \\
\hline & $\begin{array}{l}\text { Stockholm, Gøteborg, Sweden. } \\
\text { Bergen, Oslo, Norway. }\end{array}$ & $\begin{array}{l}\text { Universities of Stockholm and Gøteborg. } \\
\text { University of Bergen and Hogskules, } \\
\text { Bergen and Oslo. }\end{array}$ \\
\hline & Helsinki, Finland. & College of Teacher Education. \\
\hline $1972-1981$ & $\begin{array}{l}\text { Auckland, Wellington and } \\
\text { Christchurch, New Zealand. }\end{array}$ & $\begin{array}{l}\text { The Ministry of Education, teacher } \\
\text { training institutions, Hospitals for people } \\
\text { with special } \\
\text { needs. }\end{array}$ \\
\hline 1973 & $\begin{array}{l}\text { Melbourne, Canberra, Sydney, } \\
\text { Perth, Australia. }\end{array}$ & $\begin{array}{l}\text { Drama in Education Association } \\
\text { and school districts. }\end{array}$ \\
\hline $1973-1977$ & Hobart, Tasmania, Australia. & Tasmania Teachers College. \\
\hline $1973-1980$ & $\begin{array}{l}\text { Victoria, Alberta, Ontario, Quebec, } \\
\text { Manitoba, New Brunswick, } \\
\text { Canada. }\end{array}$ & Various universities. \\
\hline $1973-1980$ & $\begin{array}{l}\text { New York State, New York } \\
\text { University, Washington DC, } \\
\text { Washington State, Minnesota, } \\
\text { Florida, North Carolina, Hawaii, } \\
\text { Idaho,Kansas, Illinois, Georgia, } \\
\text { Kentucky, California, USA. }\end{array}$ & $\begin{array}{l}\text { Various universities, colleges and school } \\
\text { districts. }\end{array}$ \\
\hline 1975 & Nairobi and Mombassa, Kenya. & The British Council. \\
\hline 1978 & Hong Kong. & British Army Schools. \\
\hline 1983 - 1984 & Haifa, Tel Aviv, Israel. & Kibbutzim and British Council. \\
\hline 1984 & Limasol, Larnaca, Cyprus. & British Council. \\
\hline 1986 & $\begin{array}{l}\text { Cape Town, Johannesburg, } \\
\text { Pretoria, South Africa. }\end{array}$ & $\begin{array}{l}\text { The South African National Drama } \\
\text { Association. (All South African work was } \\
\text { with mixed groups.) }\end{array}$ \\
\hline
\end{tabular}




\begin{tabular}{|c|c|c|}
\hline 1988 & Germany & $\begin{array}{l}\text { Volkswagen Car Works. Courses with } \\
\text { senior management for innovative } \\
\text { thinking related with production teams. }\end{array}$ \\
\hline 2006 & USA & $\begin{array}{l}\text { Universities of North Carolina and New } \\
\text { YorkWashington: American Alliance for } \\
\text { Theatre \& Education International Drama } \\
\text { Conference }\end{array}$ \\
\hline 2007 & USA & Universities of Ohio and New York. \\
\hline \multirow[t]{6}{*}{2008} & Athens, Greece & $\begin{array}{l}\text { Hellenic Theatre/Drama \& Education } \\
\text { Network, International Drama Conference }\end{array}$ \\
\hline & Tromso, Norway & International Drama Conference \\
\hline & Spetses, Greece & $\begin{array}{l}\text { Hellenic Theatre/Drama \& Education } \\
\text { Network Summer School }\end{array}$ \\
\hline & Netherlands & Drama Network of Teachers \\
\hline & Turkey & $\begin{array}{l}\text { Cagdas Drama Dernegi Conference, } \\
\text { Ankara, Turkey }\end{array}$ \\
\hline & Video link conference & $\begin{array}{l}\text { Ontario Dance \& Drama Educators, } \\
\text { Canada. }\end{array}$ \\
\hline \multirow[t]{4}{*}{2009} & Dublin, Ireland & Trinity College, Dublin. \\
\hline & Budapest, Hungary & KAVA Theatre \& Drama for Education. \\
\hline & Victoria, Canada & University of Victoria, BC, Canada. \\
\hline & Video link conference & University of Hamilton, New Zealand. \\
\hline
\end{tabular}

\section{Conferences:}

Throughout her teaching career, and since retirement, Heathcote has been in demand to attend and give keynote speeches and master classes at conferences in the UK and many countries. Her philosophy is to say 'yes' if possible, but only if she has something new to say based upon her own trialling of ideas and continuing thinking about schooling and the purpose(s) of education with implications for teacher education in the changing and ever evolving society needs, in a global world. She is always open to meeting and helping those in the teaching profession who are writing their own books and theses. She considers it to be an honour to be invited to enter into discourse by those, like herself, who are engaged in improving the ways and means of creating meaningful learning establishments.

\section{Publications:}

- "Drama for Learning", Heathcote and Bolton, Heinemann USA, 1994.

- “So you want to use role play?", Heathcote and Bolton, Trentham Books, UK, 1999.

- "Dorothy Heathcote: Collected writings on education and drama", edited by Cecily O-Neill and Liz Johnson, Hutchinson, 1984.

- "Of These Seeds Becoming", a chapter by Dorothy Heathcote in Educational Drama for Today's Schools, edited by R. Baird Schuman, The Scarecrow Press, 1978. 
- "Bolton at the Barbican" - an analysis of Gavin Bolton's work - by Dorothy Heathcote, published by SCYPT (Society for Children and Young Peoples' Theatre).

- "Heathcote at the National" - an analysis of Dorothy Heathcote's work - by Tony Goode, published by NATD (National Association of Teachers of Drama), 1982.

- Many other articles written by Dorothy Heathcote published in SCYPT.

- Article in "Teaching Thinking”, winter 2005, issue 18, focuses on Heathcote's recent work in a primary school, based on "The Crane".

- Many interviews with Dorothy Heathcote, articles, speeches and transcripts of her work, plus articles about Dorothy, have been published in drama and education journals throughout the world. She has also written manuals for students.

- $\quad$ For further references of publications by and about Dorothy Heathcote, see "Dorothy Heathcote: Drama as a Learning Medium", Revised Edition published by Calendar Island Publishers, 1999, Betty Jane Wagner, bibliography pages 243-256.

\section{Publications about Dorothy Heathcote:}

- “Dorothy Heathcote: Drama as a Learning Medium”, by Betty Jane Wagner. First edition published by National Education Association of the United States, 1976 and published in Great Britain by Hutchinson, 1979. Revised Edition published by Calendar Island Publishers, 1999.

- "Dorothy Heathcote's Story: biography of a remarkable drama teacher", by Gavin Bolton, Trentham books, 2003.

- "The Drama of History", by John Fines and Raymond Verrier, published by New University Education, 1974.

- "The Work of Dorothy Heathcote", by Fines and Verrier in the magazine "Young Drama", February 1976, Volume 4 number 1.

- "Distancing at Close Range", Stig A. Eriksson, an analysis of the common ground between Heathcote, Brecht and Ben Chaim, 2009.

\section{Film, video tapes and television:}

The Universities of Newcastle upon Tyne and Central England:

- $\quad$ The University of Newcastle upon Tyne, England, holds a large range of teaching video and DVD tapes showing Heathcote working with pupils in schools and hospitals and with children and adults with special needs. Copies of these are also available for viewing in the Heathcote archive at Manchester Metropolitan University, England.

- "Pieces of Dorothy" a biographical documentary about Dorothy Heathcote, University of Newcastle upon Tyne, 1993.

- "So Dorothy Heathcote", a biography about Dorothy's childhood, university career and using role in teaching, University of Newcastle upon Tyne, 2002. 
- The University of Central England holds an archive of teaching tapes made in schools with the master course classes.

\section{The BBC (British Broadcasting Corporation):}

- "Three Looms Waiting", The Omnibus Series, about Dorothy Heathcote, won the Blue Ribbon Prize of the Educational Film Library Association.

- "Death of a President", which involved Heathcote working with men in a reformatory institution.

- "Improvisation", a programme series for schools, in which Heathcote worked with primary and secondary aged pupils.

- "Albert", in which Heathcote used a teacher in role as a derelict, with autistic pupils.

- "Seeds of a New Life", showing Heathcote's work in a hospital school for brain-damaged children.

- "Heroes" - an interview with Heathcote as one of a series based upon interviews with accepted expert professionals.

- The teaching series "Teacher", about Heathcote's work. As a result of this series, the British Gas management commissioned Heathcote to provide middle management trainers with a programme suitable to train gas fitter apprentices when fitting appliances in homes, caring establishments and businesses.

- $\quad$ Programmes for the Open University, showing Heathcote's work with pupils aged 5, 9 and 14 , revealing their attitudes to lying, stealing and dissembling.

\section{Other:}

- Many video tapes of Heathcote's work housed in American and Canadian Universities: Wake Forest and Wilmington, North Carolina; Northwestern, Evanston, Illinois; Moscow, Idaho; Victoria, Canada; Los Angeles, California; Hawaii, New York.

- A series of Heathcote's work made in connection with the Ph.D. studies of an American Sister of Mercy in Kansas: "Making Magic", "Making History" and "Making Progress".

- Video tapes of Heathcote's teaching held in New Zealand by the NZA (New Zealand and Australian Drama in Education Association) including Maori students and immigrants.

- Video tapes made of Heathcote's work in South Africa with white, black and mixed race high school students and teachers.

- Video tapes made with Drama Associations and other Educational establishments throughout the world. 


\section{Awards and Honorary Degrees:}

1958. Awarded Honorary Master of Arts Dunelm for teaching excellence, from the University of Durham, England.

1972. The Blue Ribbon award for the BBC film biography of Dorothy Heathcote - 'Three Looms Waiting' - awarded by the Educational Film Library Association of America.

2001. The Campton Bell Lifetime Achievement Award given to Dorothy Heathcote. This award is given to artists and educators serving young people. Awarded by the American Alliance for Theatre and Education.

2005. Honorary Doctor of Letters (DLitt) awarded by the University of Newcastle upon Tyne, England.

2005. International Citation of Merit awarded to Dorothy Heathcote by ISPA (International Society for the Performing Arts) at the XIX international congress.

2007. Honorary Doctor of Education awarded by the University of Derby, England.

2008. Lifetime Achievement Award from Cagdas Drama Dernegi, Ankara, Turkey.

\section{Dorothy Heathcote's International Citation of Merit address:}

Dorothy Heathcote has been described as one of the greatest teachers of this century. In spite of being labelled an early academic failure, she was to metamorphose from "Yorkshire mill-girl weaving war-time parachutes...to internationally renowned 'guru'."

In an extraordinary career, she changed the way many teachers thought about both drama and the school curriculum. Essentially self-taught, Dorothy Heathcote was a practitioner and disseminator of a unique methodology based on the use of drama as a tool to stimulate holistic learning. Drama, when used in this way, invokes an educational process akin to a continual journey, in that learning is never completed and is always just beginning. The relevance of her methods has found a continued resonance in a wide spectrum of applications at all levels from the primary classroom to the management boardroom.

During her time as a lecturer at the University of Newcastle upon Tyne (1950-86) Dorothy Heathcote supervised many students undertaking research in drama education up to Ph.D. level, inspiring two generations of teachers and educationalists. At the same time she undertook extensive lecture tours working as both teacher and consultant all over the world.

Dorothy Heathcote's work attracted much media interest, culminating in a number of distinguished radio and television documentaries, and these have underpinned her reputation as an educationalist of world-wide significance. Her work in the field of drama education has been influential internationally and the network of those who have worked and studied with her extends into fields far beyond education. 


\section{The Heathcote Archive:}

1986. Archive initially given by Heathcote, on request, to the Theatre Department of the University of Lancaster, England.

1990. Archive transferred, by request, to the Department of Teacher Education, Manchester Metropolitan University, England.

The archive is still being incremented, as Heathcote continues to provide teaching materials, children's work and written papers, it is regularly consulted via the Internet by teachers and educators from the UK and around the world.

The archive contains a large library of Heathcote's collection of books, teaching notes, plans and papers written for individual students. It also includes work for advanced diplomas, masters and doctorate degrees written by Heathcote's students.

To be added to the archive: a library of books written for children, current publications on theatre, philosophy and literature.

As many of Heathcote's students are working and writing, there is a growing collection of their work based in Heathcote's methods later to be included in the archive, such as "A Country School History 1890-1901" and a Ph.D. on Shakespeare's sources and analysis of his plays.

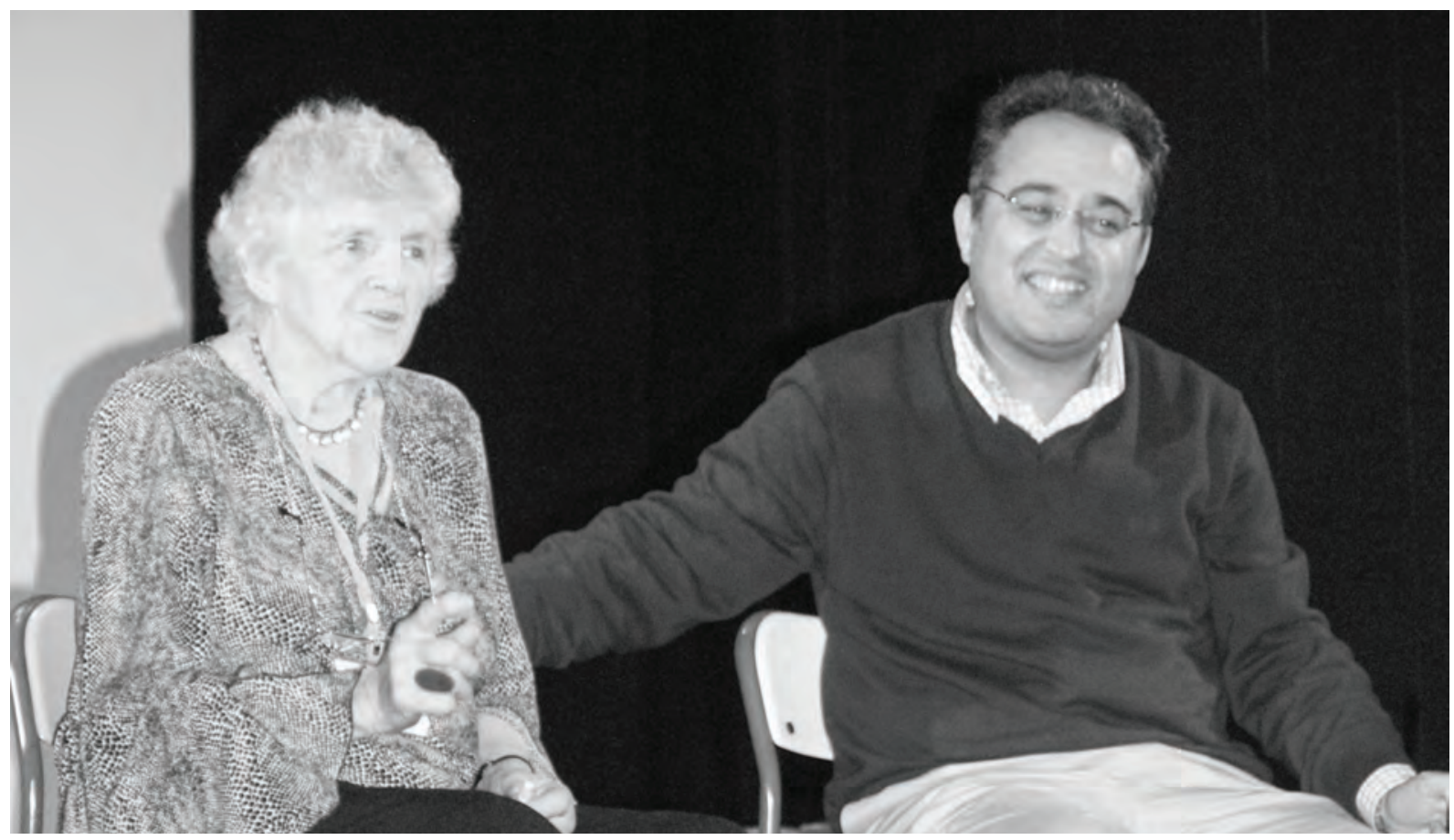

